\title{
THE EFFECT OF JOB SATISFACTION AND WORK-LIFE BALANCE ON EMPLOYEE TURNOVER INTENTION IN REAL ESTATE INDUSTRY
}

\author{
Nadira Fasya Herliana ${ }^{1}$ \\ ${ }^{1}$ Faculty of Economics, Universitas Negeri Jakarta \\ Jakarta, Indonesia \\ nadirafasya@gmail.com \\ Agung Wahyu Handaru ${ }^{2}$ \\ ${ }^{2}$ Faculty of Economics, Universitas Negeri Jakarta \\ Jakarta, Indonesia \\ ahandaru@unj.ac.id \\ Widya Parimita ${ }^{3}$ \\ ${ }^{3}$ Faculty of Economics, Universitas Negeri Jakarta \\ Jakarta, Indonesia \\ widya_parimita@unj.ac.id
}

\begin{abstract}
This study aims to: 1) To find out the description of job satisfaction, work-life balance, and turnover intention of generation $\mathrm{Y}$ employees in the real estate industry in Kebon Sirih, Central Jakarta, 2) To find out the effect of job satisfaction on turnover intention of generation Y employees in the real estate industry in Kebon Sirih, Central Jakarta, 3) To find out the effect of work-life balance on turnover intention of generation $Y$ employees in the real estate industry in Kebon Sirih, Central Jakarta, 4) To find out how much the contribution of job satisfaction and work-life balance to the turnover intention of generation Y employees in the real estate industry in Kebon Sirih, Central Jakarta. This research was conducted on 104 generation Y employees in the real estate industry in Kebon Sirih, Central Jakarta, using survey methods by distributing questionnaires processed with SPSS software version 25. The outcome of this study shows that the level of job satisfaction and work-life balance of generation Y employees in the real estate industry in Kebon Sirih, Central Jakarta is low, the story of the turnover intention of generation Y employees in the real estate industry in Kebon Sirih, Central Jakarta is high, job satisfaction and work-life balance has a negative and
\end{abstract}


significant effect on turnover intention partially, and the model of job satisfaction and work-life balance can predict employee turnover intention.

Keywords: Job Satisfaction, Work-life Balance, Turnover Intention, Generation Y

\section{INTRODUCTION}

Based on Badan Pusat Statistik Indonesia (2019) data, of 129 million Indonesian workers, 51 million workers are generation $\mathrm{X}$, and 59 million workers are generation $\mathrm{Y}$. In the following years, generation $\mathrm{Y}$ will become the main person in charge of the continuity of activities in the company. Generation y employee certainly has different characteristic compared to other generation and this should to be known and understood by the company before making a decision (Asih \& Zamralita, 2017). According to Howe and Strauss (2007), generation Y or millennials is a generation born from 1982 to 2004. Generation $\mathrm{Y}$ is known as a generation that has characteristics such as being close with technology, creative, innovative, actively explores new things, easily bored, apathetic, individualistic, egocentric, and difficult to be loyal and committed to their work (Ali \& Purwandi, 2016; and Oktariani et al., 2017).

The survey outcomes from the Deloitte Global Millenial Survey (2019) of 13.416 generation Y employees in 42 different countries (including Indonesia) stated that $49 \%$ of generation $\mathrm{Y}$ employees would leave within the next two years. Another survey results from IDN Research Institute and Alvara Research Center (2019) stated that $35.1 \%$ of 1.400 generation Y respondents in Indonesia said they would work for only 2-3 years inside the same company. These survey result described over indicate the high turnover intention of the millennial generation. The existence of turnover intention can lead to actual turnover in the company. There are several adverse effects caused by high employee turnover rates in a company related to the increase in costs, such as recruitment costs and retraining costs (Santoni \& Harahap, 2018). In addition to price, a high turnover rate in a company can also reduce company efficiency and productivity (Azeez \& Adeoye, 2016). 
Thus, the company needs to understand the elements that cause employee turnover intention, particularly generation $\mathrm{Y}$ employees within the company. Several factors that become reasons generation $\mathrm{Y}$ employees have turnover intention are job satisfaction and work-life balance (Anggraini \& Ardi, 2020).

The outcomes of the Global Leadership Study 2016 carried out by Dale Carnegie related to employee turnover intention in Indonesia show that more than $30 \%$ of employees in Indonesia plan to find another job shortly, $20 \%$ of employees have plans to change companies in the following year, and $13 \%$ of employees said they were looking for a new job. Director of National Marketing Dale Carnegie Indonesia stated that the cause of this was job satisfaction which was influenced by the behavior of superiors in the company (Liputan6.com, 2018)

Furthermore, based on the Deloitte Global Millenial Survey (2019), several of the main reasons for the emergence of generation Y turnover intention are related to job satisfaction, such as dissatisfaction with revenue or monetary wages $(43 \%)$, lack of possibilities to advance (35\%), and lack of learning and improvement opportunities (28\%). The two surveys display that one of the main motives an employee wants to leave is job dissatisfaction.

According to Robbins and Judge (2015), one of the four responses employees show when dissatisfied with their work is exit (leaving the company). On the other hand, an employee's satisfaction with his work can make the employee optimal and create an attachment to his appointment to reduce the chances of an intention to quit his job (Waspodo et al., 2019). The two statements indicate whether or not the employee is satisfied with his career affects his intention to exit the company.

In addition to job satisfaction, another element that can cause the employee intention to exit the company is work-life balance. The more significant part of respondents in a survey performed by Emancipate Indonesia of 227 young workers in Jakarta admitted that they did not encounter work-life balance (Emancipate. id, 2019). Furthermore, according to the Indonesia Millenial Report (2019) survey, as many as $83.2 \%$ of millennial juniors (20-27 years old) and $84.1 \%$ of millennial seniors (28-35 years old) show that Generation Y prefers to work with time flexibility or work free of time, so consider work-life balance. 
According to Branham (2012), one of the hidden reasons an employee leaves his company is the work-life imbalance. Employees who have an excessive workload that requires them to work overtime will lose their time with their families and time to interact with their social environment. This is often becoming one of the hidden motives an employee has to exit the company. Withdrawal signs and indications, including frequent absences and turnover, will show employees who do not experience work-life balance (Hughes \& Bozionelos, 2007). Disruption in an employee's work-life balance may cause employees to switch jobs to another enterprise or choose to stop working (Meydiana et al., 2018). Regarding the turnover intention of generation Y employees, the researcher selected two companies engaged in the real estate industry in the Kebon Sirih area, Central Jakarta, namely PT "X" and PT "Y" as research objects. PT "Y" itself is a subsidiary of PT "X," and the two companies are in the same holding, the same organizational structure, also has the exact work location in the Kebon Sirih area, Central Jakarta. From 157 employees and 62 employees at PT "X" and PT "Y," 97 and 34 employees are Generation Y, and the rest are Generation $X$. Thus, employees in both companies have been dominated by Generation Y.

Based on data obtained from HR, both companies have high turnover rates. PT "X" had a high turnover rate in 2018 and 2019 of 25.45 percent and 27.64 percent, respectively. A high turnover rate also occurred at PT "Y" in 2017, 2018, and 2019 with 12.94 percent, 19.17 percent, and 40.9 percent, respectively. Gillies stated that the employee turnover rate in the company is standard with a range of five to ten percent per year and is high when it exceeds ten percent per year (Rachim, 2020). Both companies also have an increase in employee turnover rates each year in the 2017-2019 period. In 2017, the employee turnover rate was $5.60 \%$; in 2018, it increased to $25.45 \%$, and in 2019 it increased to $27.64 \%$. While at PT "Y," the turnover rate in 2017 was 12.94 percent, then it expanded in 2018 to $19.17 \%$, and in 2019 it increased again to $40.9 \%$. Both companies need to concern about the problem of high turnover rates, judging the adverse effects that will be caused.

From the outcomes of the pre-study conducted by the researcher to 30 generation $\mathrm{Y}$ employees in both companies, it is known that generation Y employees in the real estate industry in Kebon Sirih Area, Central Jakarta, have a high level of turnover intention. It 
is reflected from 26 out of 30 employees who thought of quitting their current job, 29 out of 30 employees who intended to find a new job, and 19 out of 30 employees who intended to exit the company as quickly as possible. Judging from the outcomes of the pre-study, it was also found that job dissatisfaction and work-life imbalance are the two main reasons for employees who intend to leave the company.

In addition to the social phenomena explained over, the existence of a research gap on the variables of job satisfaction, work-life balance, on turnover intention is also the reason for the researcher to conduct this study. Research performed by Wang et al. (2020), Ibrahim et al. (2016), Lin and Huang (2020), O'Connor (2018) indicates that job satisfaction has a negative and significant effect on employee turnover intention. Meanwhile, a recent study from Dewi and Nurhayati (2021) demonstrates that job satisfaction does not influence employee turnover intention. On the other hand, outcomes of the research carried out by Fayyazi and Aslani (2015), Lestari and Margaretha (2020), and Abdien (2019) indicate that work-life balance has a negative and significant effect on employee turnover intention. In the interim, Nafiudin (2017), in his study, shows worklife balance does not influence employee turnover intention (research gap). Based on the research background, phenomenon, and research gap, the researcher took the title The Effect of Job Satisfaction and Work-life Balance on Employee Turnover Intention in the Real Estate Industry.

This research aims to find out the description of job satisfaction, work-life balance, and turnover intention of the employee in the real estate industry in Kebon Sirih, Central Jakarta, to find out the effect of job satisfaction and work-life balance on employee turnover intention partially, and to find out whether job satisfaction and work-life balance can predict employee turnover intention.

The outcomes of this research are expected to be useful theoretically and practically. Theoretically, the outcomes of this research are expected to support, complement, or refute the theory or outcomes of previous research, which is certainly useful for the benefit of science. Practically, the outcomes of this research can be used for the company to be considered in solving problems that occur within the company itself that is related to turnover intention problems. 


\section{LITERATURE REVIEW}

\section{Turnover Intention}

Mobley (2011) believes that turnover intention refers to the tendency of employees to voluntarily leave or switch jobs from one company to another according to their own choice. Nevertheless, turnover intention can also become an approximation of the level of workers who certainly want to exit the company within the close (Long et al., 2012). There will be a turnover intention when someone wants to find alternative job opportunities in other better companies (Rony, 2016). Based on this definition, turnover intention can be synthesized as an employee's tendency to withdraw from the company for various reasons, including voluntarily seeking alternative jobs in the next few months. Mobley (2011) states that turnover intention has three dimensions, namely: (1) thinking of quitting, (2) intention to search for alternative, and (3) intention to quit.

\section{Job Satisfaction}

Gibson et al. (2012) believe that job satisfaction refers to how employees think about their jobs. Job satisfaction is also associated with employees' positive emotions in their careers (Luthans et al., 2015). Job satisfaction is expressed as a positive emotion a worker feels approximately their work that comes from assessing their characteristics (Robbins \& Judge, 2015). Based on these definitions, job satisfaction can be synthesized as an employee response formulated on his feelings, both positive and negative emotions towards his work within the company.

Robbins and Judge (2015) states five dimensions can be used to measure job satisfaction, namely: (1) the work itself, (2) salary, (3) promotion, (4) supervision, and (5) coworkers.

\section{Work-life Balance}

Work-life balance can be explained as the degree of employee satisfaction perception balance at work and outside the workplace (Greenhaus et al., 2003). From the employee perspective, work-life balance can be characterized as a matter of overseeing job and personal or family duties (Lockwood, 2003). Concurring to Hayman (2005), work-life balance refers to a person's view of the balance he gets between his job and personal life. According to these definitions, the researcher synthesized work-life balance as a balance or adjust of the comparison of the sum of time a person spends doing his work with the 
sum of time a person spends doing things that are not related to his jobs, such as time with family, relaxation, and pastimes.

According to Hayman (2005), three dimensions can be used to measure work-life balance, namely: (1) work interference with personal life, (2) personal life interference with work, and (3) work/personal life enhancement.

\section{Theoretical Framework}

H1: Job satisfaction affects the turnover intention

According to research outcomes performed by Ibrahim et al. (2016), job satisfaction has a negative and significant effect on employee turnover intention in the banking industry, Nigeria. Supported by Lin and Huang (2020) which the outcomes of their research show job satisfaction have a negative and significant influence on employee turnover intention in a telecommunication company affected by restructuring in Taiwan.

$\mathrm{H} 2$ : Work-life balance affects the turnover intention

Research conducted by Abdien (2019) indicates that work-life balance has a negative and significant effect on turnover intentions of the employee in five-star affiliated hotels in Egypt. The research by Lestari and Margaretha (2020) also shows that work-life balance has a negative and significant effect on turnover intention of generation $\mathrm{Y}$ employees in Bandung, Jawa Barat, Indonesia.

H3: Job satisfaction and work-life balance can predict the turnover intention According to research outcomes performed by Fayyazi \& Aslani (2015), to examine the relationship between job satisfaction, work-life balance, and turnover intention on employees in an industrial company in Iran, job satisfaction and work-life balance has a negative and significant effect on employee turnover intention.

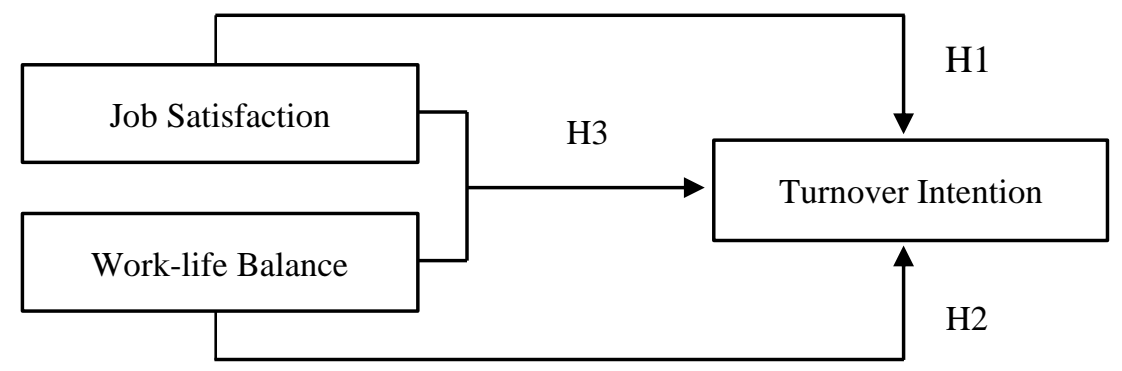

Figure 1. Research Model

Source : Data proccesed by author (2021) 


\section{RESEARCH METHOD}

This study was conducted from October 2020 to May 2021 with the object of two actual companies in the real estate industry, which are privately owned enterprises in Kebon Sirih, Central Jakarta. This study utilized a non-probability sampling technique, specifically saturated sampling. Hence, the respondent of this study is all member of the population, namely all generation Y employees at two real estate companies in Kebon Sirih, Central Jakarta, totaling 104 employees exclude managers and superiors.

This study used a 4-point Likert scale as a measurement scale of "strongly disagree" to "strongly agree" This study utilized primary data with a questionnaire as a data collection technique. For measuring job satisfaction, the researcher used five dimensions adopted from Robbins and Judge (2015). The researcher used three dimensions adopted from Hayman (2005) to measure work-life balance. For measuring turnover intention, the researcher used three dimensions adopted from Mobley (2011). Software SPSS 25 was utilized to analyze the collected data. In this study, the researcher used several data analysis techniques, namely descriptive analysis, instrument test, classic assumption test, and regression analysis test.

\section{RESULT AND DISCUSSION}

Respondents of this study were all generation $\mathrm{Y}$ employees of two companies engaged in the real estate industry in Kebon Sirih; Central Jakarta exclude managers and superiors. To make it easier for researchers to describe the research object, respondents were divided into four categories, namely based on gender, age, years of service, and education level. Of the 104 respondents, 59 or $56,70 \%$ of respondents were male, whereas the remaining 45 or $43,30 \%$ of respondents were female. Most of the respondents were in the run of 2635 years old, as numerous as 78 or $75 \%$ of the whole. For education level, the most significant number of respondents was undergraduate, as many as 90 or $86 \%$ of the total respondents. 
Table 1. Respondent Characteristics

\begin{tabular}{llcc}
\hline \multicolumn{1}{c}{ Category } & \multicolumn{1}{c}{ Characteristics } & Frequency & Percentage \\
\hline \multirow{2}{*}{ Gender } & Male & 59 & $56,70 \%$ \\
& Female & 45 & $43,30 \%$ \\
\multirow{3}{*}{ Age } & 21-25 years & 6 & $5,80 \%$ \\
& 26-30 years & 39 & $37,50 \%$ \\
& 31-35 years & 39 & $37,50 \%$ \\
\multirow{3}{*}{ Years of Service } & 36-38 years & 20 & $19,20 \%$ \\
& <1 year & 7 & $6,70 \%$ \\
& 1-3 years & 52 & $50 \%$ \\
\multirow{5}{*}{ Education Level } & 3-5 years & 27 & $26 \%$ \\
& >5 years & 18 & $17,30 \%$ \\
& SMA/SMK/equivalent & 9 & $8,70 \%$ \\
& Diploma & 2 & $1,90 \%$ \\
& S1 & 90 & $86 \%$ \\
& S2 & 3 & $3,90 \%$ \\
\hline
\end{tabular}

Source : Data proccesed by author (2021)

The Pearson Correlation (Pearson Product Moment) method is used in this validity test with SPSS version 25 as the processing software.

Table 2. Validity Test Result

\begin{tabular}{ccccc}
\hline Variable & Item & rcount $_{\text {rable }}$ & Description \\
\hline Job Satisfaction (X1) & JS1 & 0.675 & 0.361 & Valid \\
& JS2 & 0.769 & 0.361 & Valid \\
& JS3 & 0.799 & 0.361 & Valid \\
JS4 & 0.825 & 0.361 & Valid \\
& JS5 & 0.818 & 0.361 & Valid \\
JS6 & 0.728 & 0.361 & Valid \\
JS7 & 0.789 & 0.361 & Valid \\
JS8 & 0.690 & 0.361 & Valid \\
& JS9 & 0.804 & 0.361 & Valid \\
& JS10 & 0.793 & 0.361 & Valid \\
& JS11 & 0.771 & 0.361 & Valid \\
& JS12 & 0.668 & 0.361 & Valid \\
& JS13 & 0.818 & 0.361 & Valid \\
\hline
\end{tabular}

Source : Data proccesed by author (2021)

Table 2. Validity Test Result

\begin{tabular}{lcccc}
\hline \multicolumn{1}{c}{ Variable } & Item & r $_{\text {count }}$ & rtable & Description \\
\hline Job Satisfaction (X1) & JS14 & 0.808 & 0.361 & Valid \\
& JS15 & 0.764 & 0.361 & Valid \\
& JS16 & 0.857 & 0.361 & Valid \\
& JS17 & 0.806 & 0.361 & Valid \\
& JS18 & 0.632 & 0.361 & Valid \\
Work-life Balance & WLB1 & 0.814 & 0.361 & Valid \\
(X2) & WLB2 & 0.830 & 0.361 & Valid \\
& WLB3 & 0.875 & 0.361 & Valid \\
& WLB4 & 0.838 & 0.361 & Valid \\
& WLB5 & 0.739 & 0.361 & Valid \\
\hline
\end{tabular}




\begin{tabular}{ccccc}
\hline Item & r count & rtable & Description \\
WLB6 & 0.899 & 0.361 & Valid \\
WLB7 & 0.549 & 0.361 & Valid \\
WLB8 & 0.587 & 0.361 & Valid \\
WLB9 & 0.680 & 0.361 & Valid \\
WLB10 & 0.488 & 0.361 & Valid \\
WLB11 & 0.598 & 0.361 & Valid \\
WLB12 & 0.625 & 0.361 & Valid \\
WLB13 & 0.645 & 0.361 & Valid \\
WLB14 & 0.815 & 0.361 & Valid \\
WLB15 & 0.778 & 0.361 & Valid \\
WLB16 & 0.712 & 0.361 & Valid \\
WLB17 & 0.758 & 0.361 & Valid \\
WLB18 & 0.512 & 0.361 & Valid \\
WLB19 & 0.829 & 0.361 & Valid \\
TI1 & 0.893 & 0.361 & Valid \\
TI2 & 0.869 & 0.361 & Valid \\
TI3 & 0.835 & 0.361 & Valid \\
TI4 & 0.848 & 0.361 & Valid \\
TI5 & 0.622 & 0.361 & Invalid \\
TI6 & 0.280 & 0.361 & Valid \\
TI7 & 0.754 & 0.361 & Invalid \\
TI8 & 0.343 & 0.361 & Valid \\
TI9 & 0.489 & 0.361 & Valid \\
TI10 & 0.753 & 0.361 & \\
& & &
\end{tabular}

Source : Data proccesed by author (2021)

Judging from the table 2, there are 2 invalid statements because they do not meet the

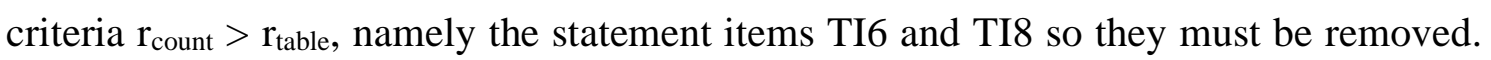
Meanwhile, the other valid statement items can be used in actual research.

Table 3. Reliability Test Result

\begin{tabular}{lccc}
\hline \multicolumn{1}{c}{ Variable } & Cronbach's Alpha & N of items & Description \\
\hline Job Satisfaction & 0.957 & 18 & Reliable \\
Work-life Balance & 0.946 & 19 & Reliable \\
Turnover Intention & 0.904 & 8 & Reliable \\
\hline
\end{tabular}

Source : Data proccesed by author (2021)

Judging from Table 3 above, each variable is declared reliable because it has Cronbach's Alpha $>0.6$.

The job satisfaction variable, when viewed as a whole, has an average percentage of answers in the category of strongly disagree (SDA) 11.39\%; the solution does not agree (DA) by $46.66 \%$; the answer agrees (A) by $35.96 \%$; and the answer strongly agrees (SA) of $5.99 \%$. Furthermore, the average percentage of the answer categories disagree (DA) and strongly disagree $(\mathrm{SDA})$ of $58.05 \%(51-75 \%=\mathrm{low})$. This indicates the low job 
satisfaction of generation Y employees in the real estate industry in Kebon Sirih, Central Jakarta.

In this variable, looking at all dimensions, some indicators have a significant influence on low employee job satisfaction. As many as $57.70 \%$ of employees feel that the tasks they do are less attractive, as many as $59.60 \%$ of employees feel that their salary is not following their workload and responsibilities. Then as many as $78.90 \%$ of employees feel dissatisfied with the opportunities provided by the company to improve their intellectual abilities and receive further education, as many as $62.50 \%$ of employees feel that their superiors in the company are still reluctant to help their subordinates when they have difficulty completing work. Also, as many as $58.70 \%$ of employees feel that their coworkers are still reluctant to assist in completing work.

The work-life balance variable, when viewed as a whole, has an average percentage of answers in the category of strongly disagree (SDA) of $6.07 \%$; the answer does not agree (DA) by $41.07 \%$; the answer agrees (A) by $45.58 \%$; and the answer strongly agrees (SA) of $7.27 \%$. Furthermore, the average percentage of the answer categories agree (A) and strongly agree $(\mathrm{SA})$ is $52.84 \%(51-75 \%)=$ low. This indicates the low work-life balance of generation Y employees of the real estate industry in the Kebon Sirih area, Central Jakarta.

In this variable, looking at all dimensions, there are indicators that have the maximum impact on the low employee work-life balance. As many as $68.30 \%$ of employees feel that their personal lives are disturbed by work, so they do not have enough time to carry out their personal lives. Moreover, as numerous as $47.10 \%$ of employees feel exhausted to carry out their work following the aimed goals. And as many as $68.30 \%$ of employees think that their work cannot make them eager when carrying out personal activities.

The turnover intention variable, when viewed as a whole, has an average percentage of strongly disagree answers (SDA) of 6.80\%; the solution does not agree (DA) by $39.33 \%$; the answer agrees (A) by 44.17\%; and the answer strongly agrees (SA) of $9.71 \%$. Furthermore, the average percentage of the answer categories agree (A) and strongly agree $(\mathrm{SA})$ is $53.88 \%(51-75 \%)=$ high$)$. This indicates the high level of the turnover intention of employees of Generation Y in the real estate industry in the Kebon Sirih area, Central Jakarta. 
In this variable, when viewed as a whole from each dimension, some indicators have the maximum impact on the high employee turnover intention. As many as $78.90 \%$ of employees think of leaving their current company when another company has a better offer. Furthermore, $61.50 \%$ of employees have the intention to find work in other companies. And $53.80 \%$ of employees feel that their performance in doing the tasks given by the company is reduced.

Table 3. Normality Test Result

One-Sample Kolmogorov-Smirnov Test

\begin{tabular}{llr} 
& & Unstandardized Residual \\
\hline N & & 104 \\
Normal Parameters ${ }^{\mathrm{a}, \mathrm{b}}$ & Mean & .0000000 \\
Most Extreme Differences & Standard Deviation & 3.02159200 \\
& Absolute & .065 \\
& Positive & .065 \\
Test Statistic & Negative & -.051 \\
Asymp. Sig. (2-tailed) & & .065 \\
\hline a Test distribution is Normal. & & $.200^{\mathrm{c}, \mathrm{d}}$ \\
b Calculated from data. & \\
c Lilliefors Significance Correction. & \\
d This is a lower bound of the true significance. &
\end{tabular}

Source : Data proccesed by author (2021)

Judging from table 4 above, obtained the significance value of $0.200(0.200>0.5)$. So, all variables in this study are proven to be normally distributed.

Table 4. Linearity Test Result Between Variable Job Satisfaction and Turnover Intention

\begin{tabular}{|c|c|c|c|c|c|c|c|}
\hline \multicolumn{8}{|c|}{ ANOVA Table } \\
\hline & & & $\begin{array}{l}\text { Sum of } \\
\text { Squares }\end{array}$ & df & $\begin{array}{l}\text { Mean } \\
\text { Square }\end{array}$ & $\mathrm{F}$ & Sig. \\
\hline \multirow{5}{*}{$\begin{array}{l}\text { Turnover } \\
\text { Intention* } \\
\text { Job Satisfaction }\end{array}$} & Between Groups & (Combined) & 1271.082 & 28 & 45.396 & 3.450 & .000 \\
\hline & & Linearity & 808.972 & 1 & 808.972 & 61.487 & .000 \\
\hline & & $\begin{array}{l}\text { Deviation from } \\
\text { Linearity }\end{array}$ & 462.110 & 27 & 17.115 & 1.301 & .187 \\
\hline & Within Groups & & 986.764 & 75 & 13.157 & & \\
\hline & Total & & 2257.846 & 103 & & & \\
\hline
\end{tabular}

Source : Data proccesed by author (2021)

Considering the results on table 5 above, obtained the significance value of 0.000 which is less than $0.05(0.000<0.05)$. So, job satisfaction variable and the turnover intention variable assumed to have a linear relationship. 
Table 5. Linearity Test Result Between Variable Work-life Balance and Turnover Intention

\begin{tabular}{|c|c|c|c|c|c|c|c|}
\hline \multicolumn{8}{|c|}{ ANOVA Table } \\
\hline & & & $\begin{array}{c}\text { Sum of } \\
\text { Squares }\end{array}$ & $\mathrm{df}$ & $\begin{array}{l}\text { Mean } \\
\text { Square }\end{array}$ & $\mathrm{F}$ & Sig. \\
\hline \multirow{5}{*}{$\begin{array}{l}\text { Turnover } \\
\text { Intention* } \\
\text { Work-Life } \\
\text { Balance }\end{array}$} & Between & (Combined) & 1572.971 & 34 & 46.264 & 4.661 & .000 \\
\hline & Groups & Linearity & 1275.006 & 1 & 1275.006 & 128.455 & .000 \\
\hline & & Deviation from Linearity & 297.965 & 33 & 9.029 & .910 & .609 \\
\hline & \multicolumn{2}{|c|}{ Within Groups } & 684.875 & 69 & 9.926 & & \\
\hline & \multicolumn{2}{|l|}{ Total } & 2257.846 & 103 & & & \\
\hline
\end{tabular}

Source : Data proccesed by author (2021)

Considering the results on table 6 above, obtained the significance value of 0.000 which is less than $0.05(0.000<0.05)$. So, the work-life balance variable and the turnover intention variable assumed to have a linear relationship.

Table 6. Multicollinearity Test Result

\begin{tabular}{|c|c|c|c|c|c|c|c|}
\hline \multicolumn{8}{|c|}{ Coefficients $^{\mathrm{a}}$} \\
\hline \multirow[b]{2}{*}{ Model } & \multicolumn{2}{|c|}{$\begin{array}{l}\text { Unstandardized } \\
\text { Coefficients }\end{array}$} & \multirow{2}{*}{$\begin{array}{l}\text { Standardized } \\
\text { Coefficients } \\
\text { Beta } \\
\end{array}$} & \multirow[b]{2}{*}{$\mathrm{t}$} & \multirow[b]{2}{*}{ Sig. } & \multicolumn{2}{|c|}{ Collinearity Statistics } \\
\hline & $\mathrm{B}$ & Std. Error & & & & Tolerance & VIF \\
\hline 1 (Constant) & 39.443 & 1.642 & & 24.022 & .000 & & \\
\hline Job Satisfaction & -.095 & .044 & -.182 & -2.135 & .035 & .565 & 1.769 \\
\hline Work-Life Balance & -.319 & .043 & -.631 & -7.390 & .000 & .565 & 1.769 \\
\hline
\end{tabular}

a. Dependent Variable: Turnover Intention

Source : Data proccesed by author (2021)

Considering the results on table 7 above, obtained the VIF value for the job satisfaction variable and work-life balance variable of 1.769 which is less than 5 . So, there is no multicollinearity within the two independent variables and the regression model is accepted.

The prerequisite for the regression model that must be met is the absence of heteroscedasticity problems, which means the significance value is $>0.05$. 
Table 7. Heteroscedasticity Test Result

\begin{tabular}{|c|c|c|c|c|}
\hline & Corre & & & \\
\hline & & $\begin{array}{c}\text { Kepuasan } \\
\text { Kerja }\end{array}$ & $\begin{array}{c}\text { Work-Life } \\
\text { Balance }\end{array}$ & $\begin{array}{c}\text { Unstandardized } \\
\text { Residual }\end{array}$ \\
\hline Spearman's Job Satisfaction & Correlation Coefficient & 1.000 & $.636^{* *}$ & -.099 \\
\hline rho & Sig. (2-tailed) & & .000 & .318 \\
\hline & $\mathrm{N}$ & 104 & 104 & 104 \\
\hline Work-Life Balance & Correlation Coefficient & $.636^{* *}$ & 1.000 & -.123 \\
\hline & Sig. (2-tailed) & .000 & 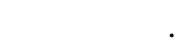 & .214 \\
\hline & $\mathrm{N}$ & 104 & 104 & 104 \\
\hline Unstandardized & Correlation Coefficient & -.099 & -.123 & 1.000 \\
\hline Residual & Sig. (2-tailed) & .318 & .214 & \\
\hline & $\mathrm{N}$ & 104 & 104 & 104 \\
\hline
\end{tabular}

**. Correlation is significant at the 0.01 level (2-tailed).

Source : Data proccesed by author (2021)

Considering the results on table 8 above, obtained the significance value from unstandardized residual to the job satisfaction variable and work-life balance variable partially of 0.318 and 0.214 which are $>0.05$. So, it is proven that there is no heteroscedasticity problem.

Table 8. Multiple Linear Regression Test Result

\begin{tabular}{|c|c|c|c|c|c|c|}
\hline & \multicolumn{6}{|c|}{ Coefficients $^{\text {a }}$} \\
\hline & \multirow[b]{2}{*}{ Model } & \multicolumn{2}{|c|}{$\begin{array}{l}\text { Unstandardized } \\
\text { Coefficients }\end{array}$} & \multirow{2}{*}{$\begin{array}{c}\text { Standardized } \\
\text { Coefficients } \\
\text { Beta } \\
\end{array}$} & \multirow[b]{2}{*}{$\mathrm{t}$} & \multirow[b]{2}{*}{ Sig. } \\
\hline & & $\mathrm{B}$ & Std. Error & & & \\
\hline \multirow[t]{3}{*}{$\overline{1}$} & (Constant) & 39.443 & 1.642 & & 24.022 & .000 \\
\hline & Job Satisfaction & -.095 & .044 & -.182 & -2.135 & .035 \\
\hline & Work-Life Balance & -.319 & .043 & -.631 & -7.390 & .000 \\
\hline
\end{tabular}

a. Dependent Variable: Turnover Intention

Source : Data proccesed by author (2021)

Considering the results in table 12, the job satisfaction variable has a tcount value of 2.135 and a significance value of 0.035 . The tcount value is then compared with the ttable value, where the ttable value is 1.984 . Thus, tcount $>$ ttable or $-2.135>1.984$ and the significance value of the job satisfaction variable is $0.035<0.05$. So, the $\mathrm{H} 1$ is accepted, and job satisfaction has a negative and significant effect on turnover intention.

In table 12, it can also be seen that the tcount for the work-life balance variable is -7.390 , and the significance value is 0.000 . This shows that tcount $>$ ttable or $-7.390>1.984$ and a significance value of $0.000<0.05$. So, the $\mathrm{H} 2$ is accepted, and work-life balance has a negative and significant effect on turnover intention.

Based on table 12, the structural equation obtained is $\mathrm{Y}=39.443-0,95 \mathrm{X} 1-0,319 \mathrm{X} 2$. 
From the structural equation, a constant of 39,443 is obtained. Therefore, if the job satisfaction variable and work-life balance variable values are 0 , the variable turnover intention is 39.443 , and it is positive. In addition, the regression coefficient obtained from the job satisfaction variable is -0.95 . Therefore, assuming that the values of other variables remain unchanged if job satisfaction increases by one unit, the turnover intention will increase -0.95 . This shows that the variable job satisfaction has a negative effect on turnover intention.

The regression coefficient of the work-life balance variable is -0.319 . Therefore, if we assume that the values of other variables remain unchanged and the work-life balance increases by 1 unit, then the value of the turnover intention will increase -0.319 . This shows that the work-life balance variable has a negative effect on turnover intention.

Table 9. F Test Result

\begin{tabular}{llrrrrr}
\hline & & \multicolumn{3}{c}{ ANOVA $^{\mathbf{a}}$} & & \multicolumn{1}{c}{ Sig. } \\
\hline 1 & Rodel & & Sum of Squares & df & Mean Square & \multicolumn{1}{c}{. } \\
& Residual & 1317.454 & 2 & 658.727 & 70.749 & $.000^{\mathrm{b}}$ \\
& Total & 940.392 & 101 & 9.311 & & \\
\hline
\end{tabular}

a. Dependent Variable: Turnover Intention

b. Predictors: (Constant), Work-Life Balance, Job Satisfaction

Source : Data proccesed by author (2021)

In table 13 , obtained $F_{\text {count }}$ of 70.749 . The $F_{\text {count }}$ value is then compared with the $F_{\text {table }}$ value. The $F_{\text {table }}$ value is 3.09. Thus, $F_{\text {count }}>F_{\text {table. }}$ From table 13 above also obtained a significance value on the F test of $0.000(0.000<0.05)$. Seen from the comparison of the $F_{\text {count }}$ with $\mathrm{F}_{\text {table }}$ and the significance value, the $\mathrm{H} 3$ is accepted. That means, the research model of job satisfaction and work-life balance can predict the turnover intention of Generation Y employees in the real estate industry in the Kebon Sirih area, Central Jakarta.

Table 10. Coefficient of Determination Test Result

Model Summary

\begin{tabular}{|c|c|c|c|c|}
\hline Model & $\mathrm{R}$ & R Square & $\begin{array}{l}\text { Adjusted R } \\
\text { Square }\end{array}$ & $\begin{array}{l}\text { Std. Error of the } \\
\text { Estimate }\end{array}$ \\
\hline 1 & $.764^{\mathrm{a}}$ & .584 & .575 & 3.051 \\
\hline
\end{tabular}

a. Predictors: (Constant), Work-Life Balance, Job Satisfaction

Source : Data proccesed by author (2021) 
From table 14, R2 has a value of 0.584 or $(58.4 \%)$. This shows that the effect of job satisfaction and work-life balance on turnover intention is $58.4 \%$, while the remaining $41.6 \%$ is influenced by other variables outside this study.

The t-test outcomes on the hypothesized model state that job satisfaction has a negative and significant effect on turnover intention of Generation $\mathrm{Y}$ employees in the real estate industry in the Kebon Sirih area, Central Jakarta. The impact of job satisfaction on turnover intention is clarified in the past research carried out by Ibrahim et al. (2016), O'Connor (2018), and Wang et al. (2020), where job satisfaction has a negative and significant effect on turnover intention. The employee will respond to their satisfaction with their work with a good attitude that can lead to positive contributions to the company, thereby reducing turnover intention. Meanwhile, dissatisfied employees can reduce the productivity and effectiveness of the organization as a whole, and if dissatisfaction occurs for a long time, it will lead to an intention to move to another company.

It is also explained by Robbins and Judge (2015) where when employees feel dissatisfied with the work they do in the company, one of the responses they can show is an exit. The exit response is defined as leaving the organization or company, including looking for alternative jobs and resigning. Thus, the job dissatisfaction felt by employees raises the intention or intention to leave the company first or turnover intention before the employee responds with actual turnover.

Based on the individual characteristics of the respondents, low job satisfaction is also influenced by the age factor where respondents are dominated by employees aged 26-35 years (as much as 75\%) which is classified as productive age and young for an employee. Young generation Y employees of the real estate industry in the Kebon Sirih area, Central Jakarta, have lower job satisfaction than older employees. This is because older employees have lower expectations and longer experience so that they can adjust better in work situations (Handoko, 2010).

In addition to age, job satisfaction is also affected by the level of education of employees. In this study, respondents were dominated by employees who have a bachelor's degree (86\%). Most of the respondents in this research have taken a high level of formal education. The higher the degree of education of a worker, the knowledge he has will be more extensive and will be progressively helped him taking care of his job, which would 
then be able to increase his job satisfaction whenever accompanied by an appropriate salary. On the other hand, job dissatisfaction felt by employees when they have high human capital (higher education and high skills) is more likely to lead them to turnover due to the many options available to move (Lee et al., 2008).

The outcomes of the descriptive analysis show the indicators that have the maximum impact on the low level of job satisfaction of Generation Y employees in the real estate industry in the Kebon Sirih area; Central Jakarta is tasks that are less attractive to employees, salaries that do not match the workload and responsibilities of employees, lack of opportunities given by the company to develop intellectually and receive further education, superiors in the company who are still reluctant to assist, and coworkers who are still unwilling to help other employees to complete work. Low employee job satisfaction will have a negative impact that will harm the company, such as increased absenteeism and employee productivity (Cherif, 2020). Furthermore, if job satisfaction is left continuously low, it can lead to turnover intention so that the company has the potential to lose its best human resources, which will later affect the company's performance. Conversely, when employees are satisfied with their work, a positive attitude will arise, contributing to optimal performance (Sunarta, 2019). Therefore, it is far essential for enterprises to be aware of the job satisfaction of their employees.

The t-test outcomes on the hypothesized model state that work-life balance has a negative and significant effect on turnover intention of Generation Y employees in the real estate industry in the Kebon Sirih area, Central Jakarta. The effect of work-life balance on turnover intention is explained in research by Abdien (2019), Fayyazi dan Aslani (2015), and Fiernaningsih et al. (2019), where work-life balance has a negative and significant effect on employee turnover intention. Efforts made through the organization in making workers feel stability in their personal and work life can reduce their intention to exit the organization. Meanwhile, an employee who experienced work-life imbalance would determine to give up their present jobs and seek different jobs that may assist them to acquire work-life balance.

In addition, it is explained by Branham (2012) where the work-life imbalance could be one of the hidden motives an employee exit the company. This can happen when employees have an excessive workload and must complete their work according to 
deadlines, requiring overtime or overtime. Thus, they have to sacrifice their time with their families to work overtime. If this happens continuously, it will cause work stress which can lead to employee intention or intention to leave the company. The low worklife balance of employees can be influenced by age. Respondents in this study were dominated by employees aged 26-35 years (as much as 75\%), were at that age employees have entered a mature age for marriage and family, so they have more responsibilities to handle at home and affect work-life balance.

The outcomes of the descriptive analysis show the indicator that has the foremost impact on the low level of work-life balance of Generation Y employees in the real estate industry in the Kebon Sirih area; Central Jakarta is the extent to which work can interfere with personal life where employees feel that their personal life is disrupted due to work such as lack of time available for work. This is because employees in the company often work overtime to meet deadlines because of the large workload. Apart from the large workload, employees in several divisions at PT X and PT Y are also required to go out of town for official duties to monitor land development so often that employees work overtime. This has an impact on employees' time being sacrificed to carry out personal activities because of work. In fact, Generation Y employees want more time outside of work to live their lives (Branham,2012). Employees also feel tired of being able to carry out work in accordance with the expected goals and feel the work done cannot make them enthusiastic when doing personal activities. In fact, Generation Y employees want jobs with workloads that are not too physically draining so that they still have enough energy to run their personal lives (Jamieson et al., 2013). Thus the company should provide entertainment and sports facilities in the office in order to relieve employee stress and keep employees in a good mood so that they can provide encouragement when doing personal activities after work.

Companies ought to pay attention to the work-life balance of their employee, considering the positive impact when employees experienced work-life balance on deportment, manner, and accomplishment (Wolor et al., 2020) and the negative impact when an employee does not experience work-life balance such as decreased productivity, decreased employee performance, and employee withdrawals (Abioro et al., 2018; \& Chermirmir et al., 2017) 
The F test outcomes on the hypothesized model state that the research model of job satisfaction and work-life balance can predict the turnover intention of generation $\mathrm{Y}$ employees of the real estate industry in the Kebon Sirih area, Central Jakarta. This outcome is supported by a past study performed by Fayyazi and Aslani (2015), which revealed a negative and significant relationship between job satisfaction, work-life balance, and turnover intention or employees at an industrial company in Iran.

\section{CONCLUSION}

The job satisfaction and work-life balance of generation Y employees of the real estate industry in Kebon Sirih, Central Jakarta are classified in the low category, and the turnover intention is classified as high. Partially, job satisfaction and work-life balance has a negative and significant effect on turnover intention of generation Y employees of the real estate industry in the Kebon Sirih, Central Jakarta, and the model of job satisfaction and work-life balance can predict the employee turnover intention.

Researcher also suggest the company to overcome employee job satisfaction problems in several ways. The company can allow employees to do other activities during working hours but still ensure employee commitment to complete their tasks on time, adjust salary payments to the employee's workload, increase intensity seminars and training for employees to increase employee knowledge and competence, and improve supervisory functions such as assisting when subordinates have difficulty working and providing solutions or suggestions if there are mistakes made by their subordinates. In the medium term, the company can provide targets and rewards for employees who successfully work beyond the target, increase the intensity of providing professional certifications for employees, hold mentorship programs in the company and increase the intensity of team building events so that bonds between co-workers are getting closer that can improve employee cooperation.

Companies can overcome employee work-life balance problems in several ways. In the short term, management should pay more attention to the working hours of its workers so as not to exceed the working hours set and agreed upon by the company. In the medium term, companies can review company policies and accommodate work-life balance policies in company policies. In the long term, the company can implement flexible 
working hours for employees as long as it does not interfere with the company's performance and provides entertainment and sports facilities to relieve employee stress and keep employees in a good mood. Companies can reduce employee turnover intention by increase job satisfaction and work-life balances.

\section{References}

Abdien, M. (2019). Impact Of Communication Satisfaction And Work-Life Balance On Employee Turnover Intention. Journal Of Tourism Theory And Research, 5(2), $228-238$.

Abioro, M. A., Oladejo, D. A., \& Ashogbon, F. O. (2018). Work Life Balance Practices And Employees Productivity In The Nigerian University System. Crawford Journal Of Business \& Social Sciences (Cjbass, 8(2), 49-59.

Ali, H., \& Purwandi, L. (2016). Indonesia 2020: The Urban Middle Class Millenials. Alvara Research Center, Februari 2016, 1-32.

Anggraini, N., \& Ardi, R. (2020). Conceptual Model For Millennial Talents Retention In Indonesia's Manufacturing Industries. Acm International Conference Proceeding Series, 148-153.

Asih, A. N., \& Zamralita, Z. (2017). Gambaran Turnover Intention Pada Karyawan Generasi Y Di Pt. Xyz (It Solution Company). Jurnal Muara Ilmu Sosial, Humaniora, Dan Seni, 1(2), 118-125.

Azeez, R., \& Adeoye, A. O. (2016). Job Satisfaction, Turnover Intention And Organizational Commitment. Bvimsr's Journal Of Management Research, 8(2).

Badan Pusat Statistik Indonesia. (2019). Keadaan Angkatan Kerja Di Indonesia Februari 2019. In Badan Pusat Statistik Republik Indonesia.

Branham, L. (2012). The 7 Hidden Reasons Employees Leave: How To Recognize The Subtle Signs And Act Before Its Too Late. American Management Association.

Cherif, F. (2020). The Role Of Human Resource Management Practices And Employee Job Satisfaction In Predicting Organizational Commitment In Saudi Arabian Banking Sector. International Journal Of Sociology And Social Policy, 40(7-8), $529-541$. 
Chermirmir, M. J., Musebe, R. O., \& Nassiuma, B. (2017). The Role Of Work Life Balance On Employee Turnover In The Flower Industry In The North Rift Kenya. International Journal Of Research In Social Sciences And Humanities, $7(1)$.

Deloitte Touche Tohmatsu Limited. (2019). The Deloitte Global Millennial Survey 2019. Deloitte.

Https://Www2.Deloitte.Com/Content/Dam/Deloitte/Global/Documents/AboutDeloitte/Deloitte-2019-Millennial-Survey.Pdf

Dewi, R. S., \& Nurhayati, M. (2021). The Effect Of Career Development On Turnover Intention With Job Satisfaction And Organizational Commitment As Mediators, Study At Pt Control Systems Arena Para Nusa. European Journal Of Business And Management Research, 6(4), 11-18.

Emancipate.Id. (2019). Open Discussion: Work-Life Balance Of Young Worker In Indonesia. Https://Emancipate.Id/Uncategorized/Open-Discussion-Work-LifeBalance-Of-Young-Worker-In-Indonesia/

Fayyazi, M., \& Aslani, F. (2015). The Impact Of Work-Life Balance On Employees’ Job Satisfaction And Turnover Intention; The Moderating Role Of Continuance Commitment. International Letters Of Social And Humanistic Sciences, 51(Im), $33-41$.

Fiernaningsih, N., Nimran, U., Rahardjo, K., \& Arifin, Z. (2019). Do Work Life Balance, Organizational Pride And Job Satisfaction Affect The Intention To Leave? International Journal Of Recent Technology And Engineering, 8(3), 1217-1223.

Gibson, J. L., Ivancevich, J. M., \& Konopaske, R. (2012). Organizations: Behavior, Structure, Processes (P. Ducham (Ed.); 14th Editi, P. 658). Mcgraw-Hill Irwin.

Greenhaus, J. H., Collins, K. M., \& Shaw, J. D. (2003). The Relation Between WorkFamily Balance And Quality Of Life. Journal Of Vocational Behavior, 63(3), $510-531$.

Handoko, H. (2010). Manajemen Personalia Dan Sumber Daya Manusia. Bpfe Yogyakarta. 
Hayman, J. (2005). Psychometric Assesment Of An Instrument Designed To Measure Work Life Balance. Research And Practice In Human Resource Management, 13(1), 85-91.

Howe, N., \& Strauss, W. (2007). The Next 20 Years: How Customer And Workforce Attitudes Will Evolve. Harvard Business Review, 85(7-8), 41-52.

Hughes, J., \& Bozionelos, N. (2007). Work-Life Balance As Source Of Job Dissatisfaction And Withdrawal Attitudes: An Exploratory Study On The Views Of Male Workers. Personnel Review, 36(1), 145-154.

Ibrahim, M. G., Hilam, H., \& Kaliappen, N. (2016). Effect Of Job Satisfaction On Turnover Intention: An Empirical Investigation On Nigerian Banking Industry. International Journal Of Organizational \& Business Execellence, 1(2).

Idn Research Institute. (2019). Indonesia Millennial Report 2019: Memahami Perilaku Milenial Indonesia. Idn Research Institute. Https://Www.Idntimes.Com/Indonesiamillennialreport2019

Jamieson, I., Kirk, R., \& Andrew, C. (2013). Work-Life Balance: What Generation Y Nurses Want. Nurse Leader, 11(3), 36-39.

Lee, T. H., Gerhart, B., Weller, I., Trevor, C. O., \& Ellig, B. R. (2008). Understanding Voluntary Turnover: Path-Specific Job Satisfaction Effects And The Importance Of Unsolicited Job Offers. Academy Of Management Journal, 51(4), 651-671.

Lestari, D., \& Margaretha, M. (2020). Work Life Balance, Job Engagement And Turnover Intention: Experience From Y Generation Employees. Management Science Letters, 11, 165-170.

Lin, C. Y., \& Huang, C. K. (2020). Employee Turnover Intentions And Job Performance From A Planned Change: The Effects Of An Organizational Learning Culture And Job Satisfaction. International Journal Of Manpower.

Liputan6.Com. (2018). Terkuak, 30 Persen Karyawan Ri Ingin Pindah Kerja. Https://Www.Liputan6.Com/Bisnis/Read/3216157/Terkuak-30-PersenKaryawan-Ri-Ingin-Pindah-Kerja

Lockwood, N. R. (2003). Work/Life Balance: Challenges And Solutions For Human Resource Management. In Shrm Research (Issue Research Quarterly). 
Long, C. S., Thean, L. Y., Ismail, W. K. W., \& Jusoh, A. (2012). Leadership Styles And Employees' Turnover Intention: Exploratory Study Of Academic Staff In A Malaysian College. World Applied Sciences Journal, 19(4), 575-581.

Luthans, F., Luthans, B. C., \& Luthans, K. (2015). Organizational Behavior: An Evidence Based Approach (13th Efiti). Information Age Publishing Inc.

Meydiana, E., Prasetya, A., \& Sulistyo, C. W. (2018). Analisis Faktor-Faktor Yang Mempengaruhi Turnover Intention Pada Karyawan Generasi X Dan Generasi Y (Studi Pada Karyawan Pt Abc Sidoarjo). Jurnal Administrasi Bisnis, 61(3).

Mobley, W. H. (2011). Pergantian Karyawan: Sebab-Akibat Dan Pengendaliannya (N. Imam (Ed.)). Pt Pustaka Binaman Pressindo.

Nafiudin. (2017). Analisis Turnover Intention Karyawan Generasi Y Di Provinsi Banten Serta Faktor Yang Mempengaruhinya. Jurnal Penelitian Ekonomi Dan Bisnis, 2(1), 1-9.

O'connor, J. (2018). The Impact Of Job Satisfaction On The Turnover Intent Of Executive Level Central Office Administrators In Texas Public School Districts: A Quantitative Study Of Work Related Constructs. Education Sciences, 8(2).

Oktariani, D., Hubeis, A. V. S., \& Sukandar, D. (2017). Kepuasan Kerja Generasi X Dan Generasi Y Terhadap Komitmen Kerja Di Bank Mandiri Palembang. Jurnal Aplikasi Bisnis Dan Manajemen, 3(1).

Rachim, F. T. G. M. (2020). Pengaruh Kepuasan Kerja Dan Beban Kerja Terhadap Turnover Intention Pada Karyawan Pt Atoz Mega Indonesia. Universitas Negeri Jakarta.

Robbins, S. P., \& Judge, T. A. (2015). Perilaku Organisasi (16th Ed.). Salemba Empat.

Rony, Z. (2016). Siapa Harus Pergi Siapa Harus Tinggal: Strategi Mencegah Turnover Karyawan Gen-Y. Pssdm.

Santoni, A., \& Harahap, M. N. (2018). The Model Of Turnover Intentions Of Employees. International Review Of Management And Marketing, 8(6), 93-100.

Sunarta. (2019). Pentingnya Kepuasan Kerja. Jurnal Efisiensi - Kajian Ilmu Administrasi, $16(2), 63-75$.

Wang, H., Jin, Y., Wang, D., Zhao, S., Sang, X., \& Yuan, B. (2020). Job Satisfaction, Burnout, And Turnover Intention Among Primary Care Providers In Rural 
China: Results From Structural Equation Modeling. Bmc Family Practice, 21(1), $1-10$.

Waspodo, A. A., Lindawati, \& Sholikhah. (2019). Pengaruh Kepuasan Kerja Dan Lingkungan Kerja Terhadap Organizational Citizenship Behavior Karyawan Perum Damri Kantor Pusat. Journal Of Chemical Information And Modeling, 10(1), 1689-1699.

Wolor, W., Kurnianti, D., Zahra, S. F., \& Martono, S. (2020). The Importance Of WorkLife Balance On Employee Performance The Importance Of Work-Life Balance On Employee Performance Millennial Generation In Indonesia. Journal of Critical Reviews, 7(9). 